\title{
Youth Bulge and Income Generating Activities [IGAs]: A Case of Youth Livelihood Programme [YLP] in Wakiso District, Central Uganda
}

\author{
Sendawula Noah, Edaku Charles, Andrew P. Yiga \\ Nkumba University, Entebbe, Uganda \\ Email: noahsendawula@nkumbauniversity.ac.ug
}

How to cite this paper: Noah, S., Charles, E., \& Yiga, A. P. (2021). Youth Bulge and Income Generating Activities [IGAs]: A Case of Youth Livelihood Programme [YLP] in Wakiso District, Central Uganda. Open Journal of Social Sciences, 9, 470-487. https://doi.org/10.4236/jss.2021.95026

Received: April 26, 2021

Accepted: May 22, 2021

Published: May 25, 2021

Copyright $\odot 2021$ by author(s) and Scientific Research Publishing Inc. This work is licensed under the Creative Commons Attribution International License (CC BY 4.0).

http://creativecommons.org/licenses/by/4.0/

\begin{abstract}
The study focused on the need for income generation activities as a response to the challenge of a bulging youth population. When neglected, youth bulge has effects on the socio-economic development process of countries that could result into catastrophic consequences especially for poor countries whose ability to plan, provide for and reap demographic dividends is low. Globally, historical and current analysis of conflicts, suggest that between 1970 and 1999 , close to $80 \%$ of civil unrest and conflict took place in countries with $60 \%$ of their population below age of 30 . Utilising a qualitative research approach, this study took a case of Wakiso district in central Uganda, to examine the extent to which the youth livelihood programme (YLP) has enable youth set up income generating activities for self-employment. YLP was an initiative of the Government of Uganda (GOU) to assist multitudes of youth acquire employment and improve their standards of living with a view of averting the negative consequences of bulging youth population (MGLSD, 2013). Data was collected using group and in-depth interviews, documentary review, and observation. A sample of 67 respondents was purposively selected. Findings revealed that, the financial support extended to youth was awfully inadequate to facilitate and support establishment of effective and sustainable IGAs. Furthermore, it was awfully, it was established that, YLP opted to deal with youth who had already established enterprises with own capital from various sources and as such, rather than provide financial support for youth to establish IGAs, YLP facilitated recapitalization and boosting of existing youth enterprises. The study recommended that, YLP overhauls its operational framework to enable provision of adequate financial support and include youth without running enterprise among target beneficiary categories since they are equally distressed and needy.
\end{abstract}




\section{Keywords}

Youth Bulge, Income Generating Activities, Youth Livelihood Programme [YLP], Wakiso District

\section{Introduction}

Youth bulge, a term popularized by German social scientist Gunnar Heinsohn in mid 1990s is used in describing circumstance in which a fast growing youthful population could result in catastrophic consequences especially for countries whose ability to plan, provide, and take advantage of the demographic shifts is low or entirely lacking (PAI, 2007) while a growing frustration and competition for economic opportunities and jobs among youth may not directly fuel violence, it enhances the possibilities of unemployed youth seeking economic and social advancement through alternative means. According to (Gavin, 2007), "if youth have no other options and not much else is going on, then opportunity cost of joining rebellion and armed movements may be low".

Globally, historical and current analysis of conflict, suggest that between 1970 and 1999 , close to $80 \%$ of civil unrest and conflicts took place in countries in which $60 \%$ of their populations are below age of 30. According to PAI (2007) report, currently there are sixty six countries experiencing youth bulges of which, sixty are experiencing violence and severe social unrest. Although youth bulge is not a bad phenomenon, countries require adequate, progressive and dynamic economy to provide for productive enterprise in order to reap demographic dividends. This is not the case with majority of countries in sub Saharan Africa and other regions in the developing world (Daumerie \& Madsen, 2010).

\subsection{Dealing with Youth Bulge}

Development Institutions and scholars such as (Daumerie \& Madsen, 2010; Ortiz \& Cummins, 2012; World Bank, 2011) strongly recommend adoption and implementation of economic policies that support creation of employment opportunities as it is seen as a quick response measure for addressing demographic related challenges and enabling countries reap demographic dividends (World Bank, 2011; UNCTAD, 2020).

Uganda is one of the countries in sub Saharan Africa that has not been spared by the threats of a bulging youthful population. With a youthful population of more than $75 \%$ below age of 30 , and contending with one of the highest unemployment rates in the region, just like other sub Saharan African countries, Uganda has and continues to experience bouts of social unrest and tension largely driven by frustration related to its rigid economic system and an already strained labour market (Daumerie \& Madsen, 2010).

World Bank, 2011 and Daumerie \& Madsen, 2010 contend that country's like Uganda needs to prioritise investments in productive activities in order to turn 
youth bulge into demographic dividends. Subsequently, the government of Uganda (GOU), through the ministry of gender labour and social development (MGLSD) initiated the youth livelihood programme (YLP) whose primary objective was to among others support the youth in their livelihood endeavors by providing funds to enable creation of income generation activities for improved and sustainable livelihoods.

\subsection{Problem Statement}

Youth bulge is a phenomenon associated with enormous challenges of a socio-economic, political and other nature due to its potential catastrophic consequences on the economy, political landscape and social set-up of countries. Conflicts, social tension and other disruptions of social order often result from lack of capacity by affected countries to reap a demographic dividend hence resulting in a demographic bomb (World Bank, 2014; Gavin, 2007). Sizeable numbers of youth agitated by the failure to secure employment and meaningful income, turn into political and social instabilities.

The Government of Uganda through the Ministry of Gender, Labour and Social Development (MGLSD) initiated YLP in 2013 as partial effort to avert negative consequences of a bulging youth population by among other things providing financial support to enable youth to establish own income generating activities [IGAs] for improved livelihoods and better standards of living (MGLSD, 2013). However, despite such effort, youth unemployment rates remain alarmingly high, their livelihoods remain unsustainable and their standards of living still awfully low.

According to the World Bank (2019), although youth unemployment rate in Uganda has been stagnating in some cases, it has remained alarmingly high. In 2012 , youth unemployment rate was peaked at $5.2 \%$ slightly declining and stagnating at $2.46 \%$ before rising again to $2.59 \%$ in 2018 . The NDP II, GOU (2015/16-2019/20), indicated that poverty levels across regions remain high. Equally disturbing is a report by UBOS (2015) in which it was observed that rural areas holding a bulk of youthful population constitute $89.3 \%$ of national poverty levels. In Wakiso district, YLP was rolled out in 2013 to among other things offer financial support for youth to establish IGAs and lower unemployment rates (MGLSD, 2013). However, Wakiso district retains one of the highest incidences of youth unemployment. While the national youth unemployment rate stands at $64 \%$, Wakiso district accounts for $28 \%$ of that bulk (UBOS, NHS 2016/2017). The increasing trend of youth unemployment despite the YLP initiative remains the key question for the researcher.

\section{Literature Review}

\subsection{Understanding Income Generating Activities (IGAs)}

Income generating activities take many forms. Originally, it was a term used only by economists to explain the intricacies of a nation's economy. However, it is 
now quite widely used to cover a range of productive activities by people in the community (Mungai, 2009). Income generating activities simply means those activities affecting the gaining or increasing of income by an individual person. However, the International Labour Organisation Resolution, ILO (2003) defines income generation activities as any activity that generates income, the income could be in cash or in king and are received by either household or individual members of a household at more frequent intervals, but exclude other such irregular and typically one time receipts.

There are three ways income can be generated. Firstly, income generating activities do not always mean the immediate getting of money, although in the end we use money to place a measurable value on the goods and services people produce (ACF International, 2009). An example of income generating activity which does not lead to getting money would be a situation where a productive person produces enough food to feed him or her and family. In that case, skills have been used to meet immediate needs and thus savings have been achieved. Money value can be placed on the food produced and so the food can be seen as an income (ACF International, 2009). A second way a person can generate income is by astute investment of existing resources. An example would be development of a piece of land through planting a crop for sale. The money gained is income. An indirect form of investment is on bank savings or purchasing part of ownership (shops) in a productive enterprise such as business. Money generated from such investments is income (ACF International, 2009).

A third way to generate income is for people to use their skills by serving another person who pays for the use of the skills. That is they earn wages. Income can also be generated by self-employment by adding to a personal resource through investment (ACF International, 2009). According to UNDP Annual Report (2007), the limits of a welfare oriented response to the growing crisis of unemployment are now well recognised many development agencies and governments are increasing their emphasis on assisting citizens to secure income through their own efforts. Such approaches are often categorised as "income generating activities" and cover initiatives as diverse as small business promotion, cooperative undertakings, job creation schemes, credit and saving groups; and youth training programmes. It is sometimes argued that education and health provision, legal and political changes, and global economics all affect the abilities of people to secure an income. From this, stems the confusion in the use of the term income generation.

It is argued that income generating activities are those initiatives that affect the economic aspects of people's lives through the use of economic tools such as credit. However, according to Mungai (2009), income generating activities are "small scale projects that create an income source to individual beneficiaries or beneficiary groups while promoting the principal right to self-determination and the objectives of integration, repatriation and re-integration". De Klerk (2002) uses the notion of income generation relatively broadly and as a cover term for a wide variety of activities such as micro credit, grants, skills, and vocational training 
business training, cash or food for work (asset creation) schemes, local economic development initiatives, and even small and medium enterprises development.

In the strict sense of the term, income generation activities are aimed at creating a financial income. Income generating activities however, may also aim at positive effects in terms of empowerment, self-reliance and community development (Ison, 1996). HDR (1996) stated that, income generation activity is related to all activities that result in a return in cash or in kind. Moreover, income generating activities can also refer to on farm activities that result in sale or barter, off-farm activities that involve a production skill that results in a product for sale or barter, processing activities which take an agricultural raw material or any product that may provide those involved with a value added income, service industries such as trading, hotels and restaurants (Ison, 1996).

According to Mungai (2009), income generating activities are the activities focused on creating opportunities for communities to productively use locally available resources to develop less state dependent, more self-reliant households and communities able to care for themselves. Income generating activities focus on productively using locally available resources to the benefit of the entire community. In addition, IGAs provide additional benefits that reduce poverty, improve the wellbeing of the communities as well as empowerment, self-reliance and community development (Rajamma, 1993).

In Africa, a number of conditions affect the ability of groups and individuals to initiate and sustain income generating activities. According to Mungai (2009), the unavailability of financial resources, commonly referred to as "capital" has played as a great disincentive to many communities. Research indicates, that the few existing cases of success with IGAs have been due to individual or groups access to financial support either through established mechanisms by governments or access to financial resources with help of collaterals. In cases were financial resources have been extended to support IGA initiatives, evidence available indicates an increase in income for the poor providing them greater freedom to make choice about how to further improve their lives. It has allowed the previously poor to build assets, reduce vulnerability to disasters and improve their food security (Uphoff \& Louise, 2006).

\subsection{Financial Support as Means for Income Generating Activities (IGAs)}

To ensure income generating activities (IGAs) are initiated, financial support plays a crucial role. The components of financial factor contributing to initiative and success of income generating activities are finance availability and accessibility (Ortiz \& Cummins, 2012). Financial availability and accessibility are cited in many studies as being one of the major barriers and constraints to growth, success and sustainability of income generating activities. In a study of Non-Governmental Organisations and women small scale entrepreneurs in the government manufacturing sector of the textile industry in Nyeri and Nairobi by (Macharia \& Wanjiru, 1998 in ILO, 2008), the factors that inhibit initiative, suc- 
cess, sustainability of such income generating activities among women included; lack of start-up (seed) capital, lack of awareness of existing credit schemes, high interest rates and lack of collateral security for finance. The lack of financial support has become a major barrier to the initiative and growth potential of businesses and income generating activities initiated by vulnerable youth (World Bank, 2009).

It is recorded, that youth constitute the largest percentage of Uganda's population but few own land title deeds and other assets accepted as security for access to financial resources. The requirement for big collateral as security for access to financial resources is still a hurdle for most vulnerable youth given that in most cases they do not own property (Haji \& Haji, 2007). In Uganda, the government has made effort to solve this problem through design and implementing youth focused programmes aimed at skilling and providing financial assistance for productive assets. In the past, accessibility to initial capital, even when available, accessibility is still a major hurdle for most young people and as such contributing to their inability to engage in various income generating activities.

It is important to note that micro credit has been emphasised as means to solve the unemployment problem through support for income generating activities but it is not an end in itself as other factors must be integrated. For the case of micro finance institutions and commercial banks that provide financial support, these choose their own terms in relation to location, conditions for access and utilization of their facilities, this has greatly contributed to disparities in terms of accessing financial support for income generating activities (UNESCO, 2004). However, for the case of Uganda, under the new framework of design and implementation of youth focused programmes such as (YLP), financial support is no longer a constraint as access is guaranteed under program design (MGLSD, 2013).

While government has undertaken measures to ensure financial support, for income generating activities, their effectiveness to date remain inappropriate due to inadequacy of program funding, poor follow up mechanisms, implementation and related management dynamics. According to a study carried out by Action against Hunger International (2009), findings indicated that the more that is invested as initial capital for income generating activities, the greater the chances of success. However for the case of income generating activities, funding for effective implementation has often been in short supply. For vulnerable populations as youth, it has been preferable to initiate income generating activities that require lower amounts of capital and yet according to Stevenson and Stonge (2005), insufficient capital was identified as a cause for sustainability failure for most income generating activities.

\section{Methodology}

The study adopted a qualitative descriptive phenomenological design which according to (Creswell, 2013; Holloway \& Wheeler, 2002), is appropriate for qualitative studies and has an object of focusing on commonality of lived expe- 
riences within particular groups. As such, the fundamental goal of phenomenology research design is to assist arrive at an effective description of nature of the particular phenomenon (Wertz, 2005). Regarding this study, phenomenology as a research design enabled the researcher to undertake descriptions of experiences of respondents in regard to the different aspects of youth livelihood programme and income generation activities among youth in Wakiso district.

In line with qualitative research approach, the study adopted interpretivism research philosophy which according to Bernstein (1995), is predicated on the argument that there can be no understanding of social world without interpretation. Basing on interpretivism assumption that reality can be constructed, the researcher was able to make own interpretations and deductions on a wide range of aspects of interest to the study. The study utilised a qualitative approach because it facilitates dealing with situations requiring assessment of attitudes, opinions and behaviors likely to be of a subjective nature. Ritchie \& Lewis (2003), concur that qualitative research approaches embrace methods that enable the researcher to address research questions that require explanations or understanding of social phenomenon and their context. This approach facilitated the research in investigating YLP and Income generating activities among youth by interacting with youth who are beneficiaries of YLP financial support. This enabled deeper understanding and interpretation of meanings and experiences of participants.

Taking Wakiso district as an area of focus, a detailed investigation of the problem was undertaken. The preference of Wakiso district was due to the fact that it was one of the initial areas where YLP was rolled out and yet it also boosts a large number of unemployed youth. With help of a purposive sampling technique, the respondents were selected on the basis of their engagement with and knowledge of YLP. Considering that this was a qualitative study, the researcher did not set out with a predetermined number of respondents and as such, sample size was not obtained on basis of numerical representativeness but rather on prospects for in-depth information.

In line with Glaser \& Strauss (1968) advice that researcher may continue interacting with different sections of respondents until no new information is realised, a sample of 67 was obtained. To effectively obtain data, the researcher utilised in-depth and group interviews, documentary review and observation methods which are appropriate in qualitative studies. In particular, in-depth interviews were conducted with local leaderships in YLP beneficiary areas of operation (LCs), community development officers (CDOs) \& selected YLP officials at the sub county and district levels. Documents reviewed included those relating to YLP processes at the different levels of implementation. The nature of Income generating activities (livelihood activities), assets, toolkits acquired and being utilised and products constituted key observable aspects. Interviews facilitated interaction-a one on one engagement with concerned sections of participants. 


\section{Discussion of Findings}

Income generating activities (IGAs) are a critical part of any endeavors aimed at achieving sustainable youth livelihoods for which the Youth Livelihood Programme (YLP) was purposed. In this section, findings of the study are presented, interpreted and discussed in detail. To exhaustively address the study objective, the main research question was broken down into sub questions to which responses were sought. Findings in respect of sub questions and corresponding themes are presented and discussed below.

\subsection{Respondents Income Generating Activities (IGAs)}

The findings here are in respect of responses to the sub question on the kind of income generating activities respondents were engaged in. The different clusters of respondents interviewed were involved in a variety of livelihood activities and these included; poultry farming, brick laying, baking, piggery, functional hire services, tree nursery and seedling growing, home \& body care products, crafts \& shoe making, carpentry \& furniture works, welding \& metal fabrication, mushroom growing, catering services and Transportation (Boda-Boda) services.

Findings from observation were indeed in support of the above narrative. My observations of what was going on in the field indicated that, indeed YLP beneficiaries are engaged in a wide range of enterprises from which they earn a livelihood as indicated in the plates below (Figure 1).

The responses indicated that respondent's economic activities span a variety of income generating activities. Findings indicated that majority (12) representing $18 \%$ of total respondents were engaged in piggery, while (11) representing $16 \%$ were into poultry. Findings also indicated that (10) beneficiaries representing $15 \%$ of total respondents were involved in welding and metal fabrication followed by carpentry and furniture works at (07) $10 \%$ respectively. Mushroom growing (02) 3\%, tree nursery and seedling growing (01) $2 \%$ and baking (02) 3\% stand out as the activities with least involvement. The findings therefore generally suggest that, poultry farming, piggery, carpentry and furniture works, welding and metal fabrication are the most outstanding IGAs constituting respondents income generating activities. It can be argued based on the findings that respondents opted for activities with high possibility of market
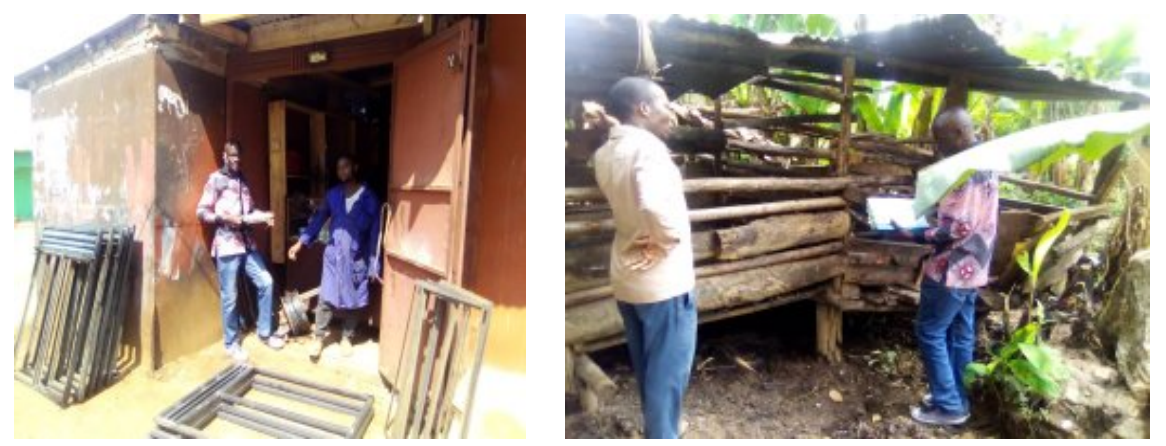

Figure 1. YLP beneficiary enterprises. 
acquisition and returns on investment (ROI) as observed by one of the respondents that:

“... getting YLP money and being able to utilise it with good returns are two different things. Regardless of what you are doing, money has to be returned and so it's important to engage in products and activities which are easy to sell. Otherwise many YLP beneficiaries are currently on the run due to inability to recoup the funds invested".

It could also be argued that respondent's choice of income generating activities was based on high activity prevalence which made it easy for beneficiaries to benchmark. Looking at mushroom growing, tree nursery and seedlings growing, and baking, one develops an impression that they are not as common as the dominant activities and as such, could present challenges with regard to benchmarking and execution. However, according to Mungai (2009), income generating activities must be focused on creating opportunities to productively use locally available resources to develop less state dependent, more self-reliant households and communities able to care for themselves. Basing on Mungai's argument, one may conclude that respondent's choice of IGAs may also have been influenced by availability of locally utilisable materials.

Related to the above sub question, respondents were asked to mention the sources of initial capital for their current enterprise and the responses are reflected below.

\subsection{Respondents Sources of Capital}

According to the results of the study, 21 respondents representing $31 \%$ of total respondents mobilised initial capital from personal savings, 19 respondents had group contributions, 18 respondents had loan from SACCO while only 09 had bank loan as source of initial capital for their current enterprises.

The theme that emerged out this study was convenience. This is supported by one of the respondents' narrative that:

"Different groups obtained their startup capital in many different ways. There are those who opted for bank loans, others went for funds from SACCOs and personal savings while some of us who were not able to access through any of those mobilised funds through group contributions. So, the ways were different depending on prevailing circumstances". (GI, 2020)

The above findings are in line with YLPs objective of extending financial resources to already established and running enterprises (MGLSD, 2013). Reliance on group contribution and personal savings also confirms the prevailing perception that banks, micro enterprises and other financial institutions have not facilitated ease of access to financial resources possibly due to the stringent requirements of collateral security coupled with high interest rates. However considering the youth as vulnerable category with minimal source from which to access capital, YLP should have been designed in a manner that facilitates opportunity for access to startup capital with less stringent requirements. 
Studies have cited financial availability and accessibility in many developing countries as a major constraints to initiative, growth, success and sustainability of IGAs (Macharia \& Wanjiru, 1998 in ILO, 2008). Furthermore, the requirements for collateral security as pre-requisite for access to financial resources is still a hurdle for most youth given that majority do not own property (Haji \& Haji, 2007) thus explaining why majority of youth are reluctant to secure financial resources for capital from banks and micro finance institutions (MFIs).

UNESCO (2004), observed that, for the case of MFIs, and commercial banks that provide financial support, these set their own terms in relation to location, conditions for access and utilization of their facilities. This act has greatly contributed to disparities in terms of access to finances for IGAs.

\subsection{Financial Support and Its Utilization}

The findings here are in respect to the sub question that required respondents to state whether they had received any financial support from YLP. Respondents who answered yes were also required to answer an additional question of how they had utilised the funds received. The responses to the question are reflected in Table 1 below followed by those to the additional question.

In the responses above, all respondents indicated that they had received YLP financial support and when asked how they had utilised such support, majority indicated that they had used funds to recapitalize; expand and in some cases sustain their enterprises.

Responses in above table indicate that (67) respondents representing $100 \%$ of total respondents received financial support in varying amounts and all the respondents pointed out that they had utilised the funds in matters of; recapitalization, expansion and enterprise sustainability. The findings therefore mean that all groups vetted as qualifying for support were given funds. Generally speaking, while many of the youth groups could have devised means of access to capital for starting IGAs, majority had been greatly constrained by lack of access to enough capital, to enable expansion and sustainability of their enterprises. Consequently, with YLP funds, majority were rescued from possible stagnation and collapse.

The theme that emerged out of this study was beneficiary support. This was supported by a narrative from sections of youth during one of the group interviews as below:

Table 1. Opinion on whether respondents received financial support.

\begin{tabular}{ccc}
\hline Opinion & Frequency & Percentage \\
\hline Yes & 67 & 100 \\
No & 0 & 0 \\
Total & 67 & $100 \%$ \\
\hline
\end{tabular}

Source: Field data, 2020. 
"Yes, we received a one off financial support from $Y L P$ and that's why we are still in business to-date otherwise our business had greatly declined due to rising costs of inputs and under capitalization". (Response from youth dealing in welding \& metal fabrication, GI, 2020)

Further responses indicated that all the youth groups that lodged in request for financial support in a given period were supported for as long as they satisfied set parameters. The respondents also indicated that the financial support received from YLP was a one-off lump sum determined by the awarding committee.

\subsection{Whether Financial Support Was Adequate or Not}

The findings here are in response to the research question of "whether the financial support was adequate in enabling respondents to grow their enterprise? In this case, respondents were free to answer yes or no. However, respondents who answered no were required to answer an additional question requiring them to indicate reasons why in their view financial support was inadequate. The findings regarding the main question are reflected below while those relating to the additional question follow.

According to the results of the study, (63) respondents representing 94\% of total respondents indicated that financial support was not adequate while only 04 respondents representing $6 \%$ of total respondents indicated that it was adequate. Respondents who indicated that financial support was adequate expressed that;

"For us we were not even expecting any funds or such support from anywhere. So, we welcomed and planned for utilization of whatever was given to $u s$ '. (GI, 2020)

Such findings confirm the general view that financial support extended to YLP beneficiaries is awfully inadequate. This factor qualifies as possible explanation for the high failure of growth of beneficiary enterprises. The revelation by one of the respondents dealing in furniture, that:

"When they submit their budgets, they are cut without due consultations with them as key stakeholders and yet budgets are made in line with project requirements", leaves one wondering as to whether YLP is really set to effectively assist youth in achieving enterprise success. According to Acs (2006), availability of adequate funds is part of interventions focused on ensuring not only the pursuit of descent but also sustainable livelihoods for majority of unemployed young men and women globally. Blanchflower and Oswald (1998), equally support the view by expressing that adequate financing for businesses can drive growth and sustainability leading to enhancement of incomes which eventually begin to accrue assets creating wealth. It is further noted that income streams that flow from ventures that are well funded are much higher and offer a sense of fulfillment than those which do not (Blanchflower \& Oswald, 1998).

Additionally, the four respondents who expressed that financial support was adequate to enable enterprise growth could be part of the minority cases in 
which youth have successfully iniated and run ventures. Access to YLP finances could have simply offered them opportunity for business expansion \& financial deepening for continuity. However, most of the respondents (63) $94 \%$ of total respondents, pointed out; kickbacks, and budget cuts as major reasons for financial inadequacy. This implies that; there is a great need to establish mechanisms that can restore \& guarantee integrity in the processing and award of YLP funds.

\subsection{Reasons for Inadequacy of Financial Support}

The respondents who answered yes were required to give reasons regarding the inadequacy of the financial support extended to them. Majority of respondents interviewed 63 representing $94 \%$ of the total respondents expressed that financial support was not adequate in enabling them to grow their enterprise. Below are the reasons advanced to explain the inadequacy.

Respondents expressed that, while YLP coordinators request for financial budgets from applicants (those who expressed interest for the funds), the budgets submitted are cut in some cases by close to half without consulting them. This left them with no option but to simply do what was possible within the approved amount.

The theme that emerged out of this section of the study was disregard for beneficiary concerns. This was supported by respondents in one of the group interviews who expressed that:

"We submitted our budget of 12 million in line with what we wanted to do. However to our surprise, it was cut by a big margin of 4 Million leaving us with only 8 Million. This affected our efforts as we could not purchase more inputs to expand production. But for lack of alternatives, we just received what was given to us". (Respondent dealing in Carpentry \& furniture Works. GI, 2020)

Other respondents claimed that the funds extended to them are subjected to deductions by way of facilitating the application process right from the stage of request for funds submission. Revealing that without facilitating the officials at the different stages, the application is likely to be frustrated and fail.

The theme that emerged from this study was corruption. To emphasise the gravity of this problem, one of the respondents stated that:

"In YLP, kickbacks are now official, if you want your application to move and be considered faster, you have to give some percentage of funds to the officials at different stages. If you don't, you can wait forever without feedback. This is why funds are never enough. Some of us borrowed to 'oip this process. (Respondent dealing in Brick laying. GI, 2020)

Other sub themes that emerged from the study were inflationary tendencies in the economy and poor communication mechanism. This is supported by the expression below by a section of respondents that:

"The processing of funds is lengthy and the bureaucracy is big. By the time you get to point of receiving money, three or more months have passed and the prices and costs of materials have changed too. It is not possible to bring such factors to the attention of officials concerned'. (Response from a section of res- 
pondents. GI, 2020)

Responses from the MGLSD officials regarding the same, indicated that financial support has largely been insufficient due to existing magnitude of need.

The theme that arose out of this was; high demand for financial support as indicated by one of the officials that:

"Because there are many youth requesting for YLP funds, money available has not been enough for all that's why we resort to budget cuts to accommodate as many beneficiaries as possible. Otherwise, as and when government allocates us more money, we shall be able to provide bigger amounts to beneficiaries". (Respondent from MGLSD. IDI, 2020)

A respondent from one of the local councils in the beneficiary area of operation argued that, while there are many reasons contributing to inadequacy of funds, the delay in fund processing has on many occasions made the funding acquisition period to coincide with scheduled dates for fund repayment and in effect, sections of beneficiaries are forced to begin repayments using the very funds received before investing them. The theme that emerged out of this study was high level of bureaucracy. This was supported by the expression below;

"The delay in releasing of funds is a big challenge in that by the time funds are released, scheduled repayment period is due. This has been the case in many areas here. So you find youth using part of the same funds to repay loan instalments. This has left them with very little to sink in their enterprises". (Local Council Chairperson from one of the beneficiary areas of operation. IDI, 2020)

\subsection{How to Ensure YLP Financial Support Stimulates IGAs}

The responses in this section are in respect of the research question "what should be done to ensure that YLP financial support stimulates income generating activities among youth in Wakiso district?" In respect of the above question. The interpretation, themes that emerged out of the study and corresponding discussion are indicated below:

\subsection{Expediting Fund Processing Period}

In respect to the above, the respondents expressed that the period within which requisitions for funds are processed is long as such often coincides with scheduled loan repayment periods and this does not allow them time to effectively invest the funds and realize the profits. In one of the group interviews, one of the respondents expressed that:

"The fund processing period takes too long and by the time we receive the money, the repayment period is already due. This does not allow us to invest all the money". (GI, 2020)

Additionally, a section of respondents also expressed that the delay in processing of funds, often leads to depletion of real value of money. The theme that emerged out of the study was inflation as one of the respondents' observed:

"The money they gave us was in Uganda shillings which is a weak currency, takes too long to come \& by the time it was given to us, inflation had already af- 
fected its value. Since government delays to release money, it should consider giving it to us in dollars instead of shillings". (Respondent dealing in Bakery business. GI, 2020)

\subsection{Availability of Equipment and Tools}

Respondents expressed the urgent need for government to avail equipment and an assortment of tools to support financed ventures. Majority of respondents argued that nothing much can be done in terms of improving value and competiveness without utilization of modern equipment $\&$ tools. The theme that arose out of the study was need for equipment $\&$ tools. This was supported by a respondent in one of the group interviews who expressed that:

"To be able to produce modern furniture, we must have the tools because most of the designs are machine made. Government must provide the tools if its intention is to see us improve and competitively sustain business". (Respondent dealing in Carpentry \& furniture works. GI, 2020)

In one of the in-depth interviews with officials from the MGLSD. One of the officials decried the failure by the YLP to avail youth with equipment and tools to enhance their productive capacity. The theme emerging out of the study was budgetary constraints which according to officials made it impossible to cater for needs of that nature. This was backed by the verbatim below:

"If the budget was big enough, procurement and supply of needed equipment \& tools would be possible, unfortunately the budget is narrow to a facilitate availability of diversity of tools \& equipment given that youth are involved in different kinds of ventures". (MGLSD Official. IDI, 2020)

\subsection{Provision of Technical Guidance and Support}

The respondents expressed that much as funds were availed, the program should have considered training and supporting the beneficiaries with technical skills to deepen their standing of their ventures.

The theme emerging from this study was skilling. In one of the group interviews, one of the beneficiary respondents expressed that:

"Although YLP was interested in groups with running ventures, technical support and capacity must be provided because technology is influencing many changes which we need to know. Unfortunately, they just gave us money and later come to collect loan installment'. (Respondent dealing in Home and Body Care Products. GI, 2020)

\subsection{Enlisting YLP Enterprises among Government Service Providers}

Regarding the above, majority the respondents expressed need for government to enlist them among service providers. In emphasizing this, majority argued that, since the current market is too competitive, enlisting them would give them an edge by guaranteeing market for their products and hence facilitating success of their enterprises. 
The theme emerging from this study was pre-qualified service provision. This was supported by verbatim below:

"Since government requires services in the different sectors, it should give us an opportunity to supply it. This is also good for it since when we succeed, we are able to pay back its money. So in a way, to support us is to indirectly support its self". (Response from a section of respondents. GI, 2020)

In one of the in-depth interviews with one of the Local Council chairpersons, he expressed the urgent need for government to review Programme by entrenching policies that compel it to purchase locally from YLP beneficiaries since their products are diverse \& they utilise government of Uganda funds. The sub theme that emerged out of the study was to enforce Buy Uganda, Build Uganda (BUBU) policy. This was supported by verbatim below:

"Although ' $B U B U$ ' policy exists, government is not compelled to buy locally from YLP beneficiaries since such decisions rest upon respective ministries and individuals vested with authority in government. There is need to enforce ' $B U B U$ ' by enlisting YLP beneficiaries as first line service providers. Such a move will not only guarantee success of enterprise but will also motivate hard work among YLP beneficiaries". ( $L C 1$ Chairperson within one of the beneficiary areas of operation. IDI, 2020)

\subsection{Adopt Mechanisms to Stop Corruption}

Findings revealed existence of systematic corruption by way of kickbacks and buying of favours right from the point of expression of interest. The theme that emerged was corruption. This was supported by respondents who expressed that:

"At every stage of fund processing, one is required to pay officials to sign and approve documents and by the time you reach to the end, you have already sunk in quite a lot. So corruption is silently interwoven in processes all the way". If you don't give money, your requests can either frustrated, delayed and in some cases abandoned totally". (GI, 2020)

Findings generally indicated that corruption through kickbacks are normal part and parcel of YLP processes involving money and all YLP beneficiaries are aware and that's why they comply to ensure successful applications.

The sub theme emerging out of the study was systemic corruption. In support of that, one of the respondent observed that:

"The level of corruption in YLP is disgusting as it is deeply rooted. This is reason why requested funds are can never be obtained in total to facilitate ventures. Since there are no ways of stopping it we just comply in order to secure the money". (Respondent dealing in Mushroom growing. GI, 2020)

In an interview with one of the MGLSD officials, he admitted knowledge of the vice but was quick to add that:

"Where there is money, you can't avoid corruption. It's not possible to stop it because everyone including some top bosses are involved. So who are you to fight an entire system?' (MGLSD official. IDI, 2020) 
Relatedly one the Community Development Officers, stated that:

"We are aware of such practices and there is need to stop corruption if, the Programme is to achieve its objectives. Corruption is slowly but surely killing YLP as many youth are increasingly failing to pay back the money". (Response from one of the CDOs in Wakiso. IDI, 2020)

The above responses indicate, need to shorten fund processing period, availing tools and equipment to support production and value addition, provision of technical guidance and support, enlisting YLP ventures among GOU service providers in order to ensure market for YLP beneficiary products and services and putting in place mechanisms to stop corruption as mechanisms to ensure YLP financial support stimulates IGAs. The findings points to a severe lack of functional institutions and mechanisms to follow, support, guide and carryout reviews to inform policy shifts for effective Programme implementation. The findings are in agreement with DIFD (2006), which argued that for youth empowerment programmes to yield positive outcomes, they should be appropriately designed with necessary mechanisms embedded to accelerate and streamline youth involvement and ensure accountability as well as better resource utilization.

Existence of rampant corruption within the multilayered fund processing chain is testimony to the fact that corruption is seriously disrupting government programmes and as such frustrating the realization of YLP Programme objectives of reducing youth unemployment through provision of skills, financial and material support for improved standards of living.

\section{Conclusion}

The paper assessed the extent to which YLP has enabled youth to establish IGAs for self-employment in Wakiso district. While YLP has reached out to youth through financial support for IGAs, overall findings indicate that financial support extended to beneficiaries was awfully inadequate to facilitate effective establishment of sustainable IGAs. Important to note is the need for establishment of effective communication channels as means of facilitating feedback between beneficiaries and YLP secretariat. Furthermore, there is also need for expedition of fund processing period, availing equipment and tools to beneficiaries, provision of technical guidance and support, adopting mechanism to curb corruption and enlisting YLP beneficiary enterprises among GOU service providers as a way of guaranteeing market for beneficiary products.

\section{Conflicts of Interest}

The authors declare no conflicts of interest regarding the publication of this paper.

\section{References}

ACF International (2009). Action against Hunger International. Annual Progress Report. 
Paris: Senegal Agency Francaise De Development (AFD).

Acs, Z. (2006). How Is Entrepreneurship Good for Economic Growth? Innovations, 1, 97-107. https://doi.org/10.1162/itgg.2006.1.1.97

Action against Hunger International (2009). Annual Progress Report, Dakar, Senegal.

Bernstein, R. J. (1995). Beyond Objectivism and Relativism: Science, Hermeneutics, and Praxis. Philadelphia, PA: University of Pennsylvania Press.

Blanchflower, D., \& Oswald, A. (1998). Entrepreneurship and the Youth Labour Market Problem. LEED Document, Paris: OECD.

Creswell, J. W. (2013). Research Design: Qualitative, Quantitative, and Mixed Methods Approaches. Thousand Oaks, CA: SAGE Publications.

Daumerie, B., \& Madsen, L. E. (2010). The Effects of a Very Young Age Structure in Uganda: Country Case Study. Washington DC: PAI.

De Klerk, T. (2002). Synthesis Report-Review of IGA Programmes of Danish Refugee Council, Danish Refugee Council.

Gavin, M. (2007). Africa's Restless Youth. Current History, 106, 220-226. https://doi.org/10.1525/curh.2007.106.700.220

Glaser, B. G., \& Strauss, A. L. (1968). The Discovery of Grounded Theory: Strategies for Qualitative Research. Nursing Research, 17, 364. https://doi.org/10.1097/00006199-196807000-00014

Haji, S., \& Haji, H. (2007). The Youth Employment in East Africa: An Integrated Labour Market Perspective. Journal of African Integration Review, 1, 67-68.

HDR (1996). Economic Growth \& Human Development. New York: UNDP.

Holloway, I., \& Wheeler, S. (2002). Qualitative Research in Nursing. Oxford: Blackwell Science.

ILO (2003). Study on Generating Employment through Micro \& Small Enterprise and Cooperative Development in Lao PDR, ILO, Geneva.

ILO (2008). International Labour Conference (9th Session, 2008), Conclusions on Skills for Improved Productivity, Employment, Growth \& Development, Geneva.

Ison, T. (1996). A Historical Perspective on Contemporary Challenges in Workers Compensation. Osgoode Hall Law Journal, 34, 807.

Macharia, K., \& Wanjiru, L. (1998). Hundreds of Women Start-Up of Enterprise in Male Dominated Sectors in Kenya. Prime Journal of Social Science, 1, 65-69.

MGLSD (2013). Youth Livelihood Programme (YLP). Kampala: MGLSD.

Mungai, J. N. (2009). Loan Repayment and Sustainability of Government Revolving Funds in Murang'a County, Kenya. PhD Thesis, Nairobi: Kenyatta University.

Ortiz, I., \& Cummins, M. (2012). When the Global Crisis and Youth Bulge Collide: Double the Jobs Trouble for Youth. Social and Economic Policy Working Paper, New York: UNICEF. https://doi.org/10.2139/ssrn.2029794

PAI (2007). The Shape of Things to Come: Why Age Structure Matters to a Safer, More Equitable World. Washington DC: PAI.

Rajamma, G. (1993). Empowerment through Income-Generating Projects. Gender \& Development, 1, 53-55. https://doi.org/10.1080/09682869308519985

Ritchie, J. B., \& Lewis, J. (2003). Qualitative Research Practice: A Guide for Social Science Students and Researchers. London: Sage Publications.

Stevenson, L., \& Stonge, A. (2005). Support for Growth Oriented Women Entrepreneurs in Uganda, ILO. Geneva. 
UBOS (2015). Statistical Abstract, UBOS, Kampala.

UNCTAD (2020). The Least Developed Countries Report: Productive Capacities for the New Decade. New York: UNCTAD.

UNDP Annual Report (2007). Making Globalisation Work for All. UNDP.

UNESCO (2004). UNESCO's Contribution to Empowering Youth through National Policies. Paris: Bureau of Strategic Planning.

Uphoff, N., \& Louise, B. (2006). Strengthening Rural Local Institutional Capacities for Sustainable Livelihoods \& Equitable Development. World Bank.

Wertz, F. J. (2005). Phenomenological Research Methods for Counseling Psychology. Journal of Counseling Psychology, 52, 167-177. https://doi.org/10.1037/0022-0167.52.2.167

World Bank (2009). Youth and Unemployment in Africa: The Potential, the Problem, the Promise. Washington DC: World Bank.

World Bank (2011). The Jobs Crisis: Household and Government Responses to the Great Recession in Eastern Europe and Central Asia. Washington DC: World Bank.

World Bank (2014). Youth Employment in Sub Saharan Africa. Washington DC: World Bank.

World Bank (2019). Youth Employment in Sub-Saharan Africa. Washington DC: Agence Française de Development \& World Bank Publications. 